\title{
FUNKCJONOWANIE PAŃSTWOWYCH FUNDUSZY REZERWOWYCH O CELU EMERYTALNYM NA PRZYKŁADZIE DOŚWIADCZEŃ NORWEGII
}

\section{Wprowadzenie}

Systemy emerytalne na całym świecie dotykają problemy związane ze zmianami demograficznymi. Spadek urodzeń i wydłużanie się przeciętnego trwania życia powodują bowiem powstawanie deficytów pomiędzy wpływami i wydatkami występującymi we wszystkich systemach opartych na umowie międzypokoleniowej. Problemy te mogą mieć charakter przejściowy, tj. wynikający z tzw. falowania demograficznego, lub trwały. W przypadku tych drugich konieczna staje się głęboka reforma rozwiązań systemowych w celu odzyskania równowagi pomiędzy wpływami i wydatkami emerytalnymi w długim okresie. Natomiast w przypadku nierównowagi przejściowej można wyprzedzająco stworzyć fundusz rezerwowy, tzw. fundusz buforowy, w którym w okresach nadwyżki wpływów nad wydatkami w systemie emerytalnym gromadzone są środki, które następnie służą sfinansowaniu świadczeń emerytalnych w latach, gdy wydatki przewyższają wpływy ze składek. Fundusze takie mogą być tworzone także ze źródeł pozaskładkowych - do najczęściej wykorzystywanych należą podatki, wpływy ze sprzedaży surowców (zwłaszcza paliw) czy wpływy ze sprzedaży majątku skarbu państwa (prywatyzacji państwowych firm).

Emerytalne fundusze rezerwowe zostały utworzone przez wiele krajów - prawie połowa państw OECD posiada takie fundusze funkcjonujące jako stałe elementy systemu zabezpieczenia społecznego lub jako tymczasowe rozwiązania wyrównawcze. Celem opracowania jest analiza sposobu gromadzenia i zarządzania największymi rezerwami emerytalnymi w Europie, tj. norweskimi państwowymi funduszami emerytalnymi. Norwegia bowiem, jako jeden z nielicznych krajów, jest przykładem kraju nadal zwiększającego i pomnażającego rezerwy emerytalne. 


\section{Geneza powstania państwowego funduszu emerytalnego w Norwegii}

Państwowy Fundusz Emerytalny w Norwegii (Statens pensjonsfond) obejmuje dwa odrębne fundusze, które są własnością państwa:

- Państwowy Fundusz Emerytalny Global (nor. Statens pensjonsfond - Utland, SPU, ang. Government Pension Fund Global, GPFG),

- Państwowy Fundusz Emerytalny Norwegia (nor. Statens pensjonsfond - Norge, SPN, ang. Government Pension Fund Norway, GPFN).

Fundusz w obecnym kształcie funkcjonuje od 1 stycznia 2006 r. Państwowy Fundusz Emerytalny Global został wówczas powołany w miejsce istniejącego wcześniej od 1990 r. Państwowego Funduszu Paliwowego (Statens petroleumsfond). Natomiast Państwowy Fundusz Emerytalny Norwegia wywodzi się z Funduszu Ubezpieczeń Społecznych (Folketrygdfondet), który został powołany w 1967 r. ${ }^{1}$

Właścicielem obu funduszy jest rząd Norwegii oraz Ministerstwo Finansów. Są one jednak zarządzane przez odrębne instytucje - za inwestycje funduszu Global odpowiada specjalna komórka wydzielona w strukturze Banku Narodowego Norwegii (Norges Bank Investment Management, NBIM), a aktywami funduszu Norwegia zarządza Folketrygdfondet ${ }^{2}$. Fundusze działają na podstawie różnych aktów prawnych i w oparciu o zupełnie inne strategie inwestycyjne. Ze względu na tak dużą odmienność zostaną omówione odrębnie.

\section{2. Źródła finansowania i polityka inwestycyjna Państwowego Funduszu Emerytalnego Norwegia}

Podstawowym celem Państwowego Funduszu Emerytalnego Norwegia, który jest zarządzany przez specjalnie powołaną do tego celu instytucję Folketrygdfondet, jest gromadzenie i inwestowanie środków emerytalnych na potrzeby wypłaty świadczeń emerytalnych w przyszłości. Aktywa zgromadzone w funduszu pochodzą

\footnotetext{
${ }^{1}$ Fundusz Ubezpieczeń Społecznych na mocy ustawy z 2007 r. stał się samodzielnym podmiotem będącym własnością państwa powołanym w celu zarządzania dwoma funduszami, w tym PFEN. M. Mosionek-Schweda, Norweski państwowy fundusz emerytalny jako inwestor na światowych rynkach finansowych, w: Ekonomiczne i społeczne aspekty reform emerytalnych - Polska i świat, red. M. Szczepański, Wydawnictwo Politechniki Poznańskiej, Poznań 2012, s. 116.

2 Ibidem.
} 
z nadwyżek, które występowały w systemie ubezpieczeń społecznych w latach 60 . i 70. XX w. W późniejszych okresach fundusz uzyskiwał dochody jedynie z działalności inwestycyjnej3.

Zgodnie z mandatem nadanym zarządzającemu funduszem przez Ministerstwo Finansów ${ }^{4}$ Folketrygdfondet otrzymał środki GPFN jako depozyt, którym powinien zarządzać w celu osiągnięcia najwyższej możliwej stopy zwrotu i dokonując niezależnych inwestycji na rynku finansowym. Działalność inwestycyjna GPFN jest ograniczona do rynku norweskiego oraz wybranych rynków krajów nordyckich (Dania, Finlandia, Szwecja) - stąd fundusz ten jest właścicielem wielu norweskich przedsiębiorstw. Aktywa funduszu mogą być inwestowane w szeroki katalog zaakceptowanych przez Ministerstwo Finansów instrumentów finansowych oraz depozyty gotówkowe. Instrumenty o stałym dochodzie powinny mieć rating zewnętrzny, a jeśli go nie mają - zarządzający powinien sam dokonać wnikliwej oceny i samodzielnie nadać rating wewnętrzny. Udział akcji w portfelu powinien wynosić $50-70 \%$ wartości aktywów netto, natomiast instrumentów o stałej stopie dochodu - od 30\% do 50\%. 80-90\% portfela powinno był ulokowane w Norwegii, a jedynie 10-20\% w Danii, Finlandii lub Szwecji. Fundusz może posiadać akcje przedsiębiorstwa norweskiego dające prawo do nie więcej niż 15\% kapitału tego podmiotu, a jeśli chodzi o przedsiębiorstwa w wybranych trzech krajach nordyckich - dające prawo do nie więcej niż 5\% kapitału5.

Folketrygdfondet może skorzystać z usług zewnętrznych podmiotów zarządzających aktywami. Wówczas struktura opłat powinna zapewniać ochronę interesów funduszu i uwzględniać horyzont czasowy inwestycji. Opłaty uzależnione od wyników inwestycyjnych powinny być ustalone w taki sposób, aby większość nadwyżki ponad bazową stopę zwrotu powiększała aktywa funduszu. Działalność funduszu jest oceniana w odniesieniu do wyników strategicznego indeksu określanego przez Ministerstwo Finansów, które wskazuje także poziom akceptowanego ryzyka i zmienności wyniku'. Strategiczny indeks składa się w $60 \% \mathrm{z}$ indeksu akcji i w $40 \% \mathrm{z}$ indeksu instrumentów o stałej stopie dochodu 7 85\% poszczególnych indeksów tworzą subindeksy dla rynku norweskiego, a pozostałe 15\% - subindeksy dla rynków wybranych

\footnotetext{
${ }^{3}$ Ibidem, s. 117.

${ }^{4}$ Management Mandate for the Government Pension Fund Norway, http://www.ftf.no/images/Marketing/Rammeverk/Management\%20mandate\%20for\%20the\%20Government\%20Pension\%20Fund\%20 Norway\%202011.pdf, dostęp 20.10.2012.

${ }^{5} \mathrm{http}: / /$ www.ftf.no/en/c-305-The-Government-Pension-Fund-Norway.aspx

${ }^{6}$ Sovereign Wealth Funds. Generally Accepted Principles and Practices „Santiago Principles”, op.cit., s. $41-42$.

7 W ramach każdego z wymienionych indeksów wyodrębnione są dwa podindeksy: dla rynku norweskiego oraz rynku innych zaakceptowanych krajów nordyckich (Dania, Finlania i Szwecja łącznie). Zob. więcej: Management Mandate for the Government Pension Fund Norway, op.cit.
} 
krajów nordyckich łącznie (Dania, Finlandia i Szwecja). Wszystkie wyniki i stopy zwrotu są kalkulowane i publikowane w lokalnej walucie (korona norweska).

\section{Efektywność inwestycyjna Państwowego Funduszu Emerytalnego Norwegia}

Do tej pory z funduszu nie dokonano żadnych wypłat. Na koniec 2010 r. w GPFN zgromadzonych było prawie 135 mld NOK $(68,46 \text { mld PLN })^{8}$. Ponad 85\% aktywów funduszu ulokowanych było na rynku norweskim - 56,2\% w akcjach, a 29,8\% w instrumentach o stałej stopie dochodu. Warto zwrócić uwagę, że faktyczne wyniki funduszu były zwykle lepsze od strategicznego indeksu wyznaczonego przez Ministerstwo Finansów - jedynie w latach 2005 i 2009 osiągnięta stopa zwrotu była o ponad 1 punkt proc. niższa od poziomu odniesienia. W okresie kryzysu finansowego w 2008 r. wszystkie indeksy akcyjne odnotowały kilkudziesięcioprocentowy spadek, co w obliczu przeważającego udziału akcji w portfelach przełożyło się na ujemną stopę zwrotu zarówno samego funduszu, jak i benchmarków. Kilkuprocentowa strata z inwestowania pojawiła się później także w 2011 r., została jednak szybko pokryta przez zyski wypracowane w roku kolejnym (tabela 1).

Tabela 1. Wyniki inwestycyjne i struktura portfela Państwowego Funduszu Emerytalnego Norwegia w latach 2005-2012

\begin{tabular}{|l|c|c|c|c|c|c|c|c|}
\hline \multicolumn{1}{|c|}{$\begin{array}{c}\text { Zyski w mIn NOK/ } \\
\text { Stopy zwrotu w \% }\end{array}$} & 2005 & 2006 & 2007 & 2008 & 2009 & 2010 & 2011 & 2012 \\
\hline Zysk & 15861 & 17385 & 10409 & -29596 & 29319 & 17812 & -5399 & 15639 \\
\hline Stopa zwrotu portfela & 9,0 & 11,1 & 9,8 & $-25,1$ & 33,5 & 15,3 & $-3,92$ & 12,16 \\
\hline Benchmark portfela & 10,8 & 10,0 & 7,2 & $-28,8$ & 35,8 & 14,7 & $-5,18$ & 11,92 \\
\hline Stopa zwrotu z norweskich akcji & 32,0 & 32,1 & 16,4 & $-49,2$ & 59,0 & 19,1 & $-10,88$ & 14,71 \\
\hline Benchmark norweskich akcji & 40,5 & 32,4 & 11,5 & $-54,1$ & 64,8 & 18,4 & $-12,45$ & 15,36 \\
\hline Stopa zwrotu z nordycki akcji & 25,1 & 24,2 & 3,0 & $-32,8$ & 17,6 & 28,2 & $-17,49$ & 15,69 \\
\hline Benchmark nordyckich akcji & 24,5 & 25,3 & 0,4 & $-37,5$ & 21,7 & 29,7 & $-16,70$ & 15,15 \\
\hline $\begin{array}{l}\text { Stopa zwrotu z norweskich } \\
\text { instrumentów 0 stałym dochodzie }\end{array}$ & 2,8 & 1,3 & 3,0 & 8,5 & 10,4 & 7,5 & 7,84 & 9,08 \\
\hline $\begin{array}{l}\text { Benchmark norweskich } \\
\text { instrumentów 0 stałym dochodzie }\end{array}$ & 3,7 & 0,7 & 3,2 & 7,8 & 8,3 & 6,7 & 6,29 & 7,68 \\
\hline
\end{tabular}

\footnotetext{
${ }^{8}$ Kurs NBP z 31 grudnia 2012 r.: 1 NOK= 0,5071 PLN.
} 


\begin{tabular}{|c|c|c|c|c|c|c|c|c|}
\hline $\begin{array}{l}\text { Zyski w mln NOK/ } \\
\text { Stopy zwrotu w \% }\end{array}$ & 2005 & 2006 & 2007 & 2008 & 2009 & 2010 & 2011 & 2012 \\
\hline $\begin{array}{l}\text { Stopa zwrotu z nordyckich } \\
\text { instrumentów o stałym dochodzie }\end{array}$ & b.d. & b.d. & 2,5 & 23,5 & $-6,3$ & 3,7 & 8,03 & 2,27 \\
\hline $\begin{array}{l}\text { Benchmark nordyckich } \\
\text { instrumentów o statym dochodzie }\end{array}$ & b.d. & b.d. & 2,7 & 24,6 & $-8,5$ & 3,1 & 7,83 & 1,11 \\
\hline \multicolumn{9}{|l|}{$\begin{array}{l}\text { Wartość aktywów w mln NOK/ } \\
\text { Udział w portfelu w \% }\end{array}$} \\
\hline Akcje norweskie & 41895 & 52471 & 60253 & 39043 & 63701 & 75791 & 66847 & 77011 \\
\hline Udziat w portfelu & 21,9 & 49,1 & 51,6 & 44,5 & 54,4 & 56,2 & 51,6 & 53,0 \\
\hline Akcje nordyckie & 8679 & 10937 & 9831 & 7441 & 9591 & 12349 & 11820 & 13673 \\
\hline Udziat w portfelu & 4,5 & 10,2 & 8,4 & 8,5 & 8,2 & 9,1 & 9,1 & 9,4 \\
\hline $\begin{array}{l}\text { Norweskie instrumenty o stałym } \\
\text { dochodzie }\end{array}$ & 140741 & 45640 & 39940 & 34106 & 36466 & 40132 & 42940 & 46383 \\
\hline Udział w portfelu & 73,6 & 40,7 & 34,2 & 38,9 & 32,0 & 29,8 & 33,2 & 32 \\
\hline $\begin{array}{l}\text { Nordyckie instrumenty o stałym } \\
\text { dochodzie }\end{array}$ & - & - & 6822 & 7161 & 6326 & 6613 & 7900 & 8079 \\
\hline Udział w portfelu & - & - & 5,8 & 8,1 & 5,4 & 4,9 & 6,1 & 5,6 \\
\hline $\begin{array}{l}\text { Goverment Pension Fund Norway, } \\
\text { aktywa ogółem }\end{array}$ & 191338 & 106940 & 117347 & 87751 & 117070 & 134882 & 129483 & 145122 \\
\hline
\end{tabular}

Źródło: http://www.ftf.no/en/c-446-Key-figures.aspx, dostęp 10.02.2012, 10.02.2014.

W ostatnich latach wielkość aktywów zgromadzonych w funduszu Norwegia systematycznie wzrasta. Na koniec 2012 r. GPFN posiadał aktywa o wartości 145 mld NOK, co odpowiada 73,6 mld PLN. Z wyjątkiem roku 2006 nie dokonywano żadnych wypłat $\mathrm{z}$ funduszu. Brak jest także informacji o planach jego wykorzystania w najbliższych latach. Pozwala to mieć nadzieję, iż środki posłużą faktycznie do sfinansowania niedoborów występujących w okresie znacznej nierównowagi w funduszu emerytalnym w okresie, w którym udział emerytów w norweskiej populacji znacząco się zwiększy.

\section{4. Źródła finansowania i polityka inwestycyjna Państwowego Funduszu Emerytalnego Global}

Państwowy Fundusz Emerytalny Global jest wykorzystywany przez rząd norweski do gromadzenia nadwyżek finansowych pochodzących ze sprzedaży ropy naftowej. Potrzebę oszczędzania na przyszłość dochodów ze sprzedaży paliw dostrzeżono już w 1974 r., kiedy parlament zwrócił uwagę, iż nieodnawialne złoża ropy naftowej powinny budować bogactwo wielu pokoleń, nie tylko ówczesnych obywateli tego 
kraju9 . Do połowy lat 90. duża część przychodów ze sprzedaży ropy naftowej była wykorzystywana na pokrycie wydatków publicznych oraz spłatę zadłużenia. Dopiero po utworzeniu Państwowego Funduszu Paliwowego część wpływów zaczęto przekazywać do funduszu, przy czym pierwsza wpłata została dokonana dopiero w 1995 r. $^{10}$

\section{Tabela 2. Etapy rozwoju polityki inwestycyjnej Państwowego Funduszu Emerytalnego} Global

\begin{tabular}{|c|c|}
\hline Rok & Najważniejsze wydarzenia dla funkcjonowania GPFG \\
\hline 1969 & Odkrycie złóż ropy naftowej na Morzu Północnym - wydobycie od 1971 r. \\
\hline 1990 & $\begin{array}{l}\text { Decyzja Parlamentu Norweskiego o utworzeniu Państwowego Funduszu Paliwowego w celu } \\
\text { długoterminowego zarządzania dochodami ze sprzedaży ropy naftowej. }\end{array}$ \\
\hline 1996 & Pierwszy transfer środków do funduszu w wysokości około 2 mld NOK. \\
\hline 1997 & $\begin{array}{l}\text { Decyzja Ministerstwa Finansów o rozpoczęciu lokowania środków funduszu w instrumenty udziałowe } \\
\text { (dotychczas fundusz inwestował jedynie w obligacje skarbowe). }\end{array}$ \\
\hline 1998 & $\begin{array}{l}\text { Rozpoczęcie działalności przez Norges Bank Investment Management (NBIM), który zarządza } \\
\text { funduszem od } 1 \text { stycznia } 1998 \text { r. w imieniu Ministerstwa Finansów. Zmienia się struktura portfela } \\
\text { inwestycyjnego - następuje konwersja 40\% wartości portfela z instrumentów dłużnych na udziałowe. }\end{array}$ \\
\hline 2000 & Do akcyjnego indeksu referencyjnego dodano pięć rynków rozwijających się. \\
\hline 2002 & Do referencyjnego indeksu instrumentów dłużnych włączono obligacje korporacyjne. \\
\hline 2004 & $\begin{array}{l}\text { Opublikowanie wytycznych dotyczących etycznego inwestowania funduszu. } \\
\text { Dołączenie do akcyjnego indeksu referencyjnego kolejnych rynków rozwijających się. }\end{array}$ \\
\hline 2006 & Zmiana nazwy na Państwowy Fundusz Emerytalny Global. \\
\hline 2007 & $\begin{array}{l}\text { Decyzja Ministerstwa Finansów o zwiększeniu limitu inwestowania w akcje z 40\% do 60\% oraz } \\
\text { włączeniu do portfela instrumentów małych i średnich przedsiębiorstw. }\end{array}$ \\
\hline 2008 & $\begin{array}{l}\text { Decyzja o dopuszczeniu możliwości inwestowania w nieruchomości do maksymalnego poziomu 5\% } \\
\text { wartości aktywów funduszu. } \\
\text { Włączenie wszystkich rynków rozwijających się do akcyjnego indeksu referencyjnego. }\end{array}$ \\
\hline 2009 & $\begin{array}{l}\text { Przegląd, ocena i weryfikacja wytycznych dotyczących etycznego inwestowania. } \\
\text { Udział akcji w portfelu funduszu osiągnął limit 60\% w czerwcu } 2009 \text { r. } \\
\text { Fundusz osiągnął rekordową stopę zwrotu } 25,6 \% \text {. }\end{array}$ \\
\hline 2010 & $\begin{array}{l}\text { Przyjęto zasady inwestowania środków funduszu w nieruchomości. } \\
\text { Ocena skuteczności aktywnego zarządzania. }\end{array}$ \\
\hline 2011 & Pierwsze inwestycje w nieruchomości zlokalizowane w Londynie i Paryżu. \\
\hline 2012 & $\begin{array}{l}\text { Nowy indeks referencyjny dla inwestycji w instrumenty dłużne. } \\
\text { Nowe zasady dywersyfikacji geograficznej inwestycji w instrumenty udziałowe. } \\
\text { Zasady korygowania indeksu referencyjnego. }\end{array}$ \\
\hline
\end{tabular}

Źródło: Opracowanie własne na podstawie: M. Mosionek-Schweda, Norweski państwowy fundusz emerytalny jako inwestor na światowych rynkach finansowych, w: Ekonomiczne i społeczne aspekty reform emerytalnych - Polska i świat, red. M. Szczepański, Wydawnictwo Politechniki Poznańskiej, Poznań 2012, s. 120 oraz The Management of the Government Pension Fund in 2012, Meld. St. 27 (2012-2013) Report to the Storting (White paper), Norwegian Ministry of Finance, Oslo, June 2013, s. 13.

9 Zob. Parliamentary Report No. 25 (1973-74) - Petroleum Industry in Norwegian Society.

10 The Management of the Government Pension Fund in 2011, Norwegian Ministry of Finance, Oslo 2012, s. 9. 
GPFG jest znacznie większy niż GPFN, głównie ze względu na dokonywanie stałych znacznych wpłat do funduszu. Ma charakter ogólnego państwowego funduszu majątkowego typu oszczędnościowego i nie jest, w przeciwieństwie do tradycyjnych funduszy emerytalnych, przeznaczony wyłącznie do celów związanych z wypłatą świadczeń dla pokolenia emerytów. Strategia inwestycyjna funduszu zakłada osiąganie możliwie najwyższej stopy zwrotu dzięki wykorzystaniu różnorodnych możliwości inwestycyjnych w długim okresie, przy zachowaniu umiarkowanego poziomu ryzyka ${ }^{11}$. Dzięki odpowiedniemu, bezpiecznemu zarządzaniu aktywami funduszu GPFG ma spowodować, że zarówno obecne, jak i przyszłe pokolenia będą mogły korzystać z bogactwa naftowego Norwegii ${ }^{12}$.

Transfer środków $\mathrm{z}$ funduszu może nastąpić $\mathrm{w}$ razie powstania deficytu w budżecie państwa, co oznacza, że fundusz jest w pełni zintegrowany z finansami publicznymi (w przypadku powstania nadwyżki budżetowej jest ona przekazywana do funduszu). Wprowadzono jednak ograniczenie wysokości środków transferowanych z funduszu do budżetu - wypłata nie może przekraczać oczekiwanej stopy zwrotu z inwestycji ustalonej na poziomie $4 \%$ w skali roku ${ }^{13}$.

Zarządzaniem aktywami funduszu zajmuje się specjalnie powołana komórka w ramach Banku Narodowego Norwegii - Norges Bank Investment Management. Fundusz inwestuje wyłącznie na rynkach zagranicznych, co zapewnia odpowiednią dywersyfikację ryzyka, zadowalający poziom stóp zwrotu z inwestycji oraz ograniczenie niekorzystnego wpływu fluktuacji cen ropy naftowej na krajową gospodarkę. Indeks referencyjny wyznaczony dla GPFG składa się w 60\% z akcji, w 35\% z papierów dłużnych i w $5 \% \mathrm{z}$ inwestycji $\mathrm{w}$ nieruchomości ${ }^{14}$. Indeks papierów dłużnych składa się z kolei w 70\% z rządowych papierów wartościowych, a w 30\% z instrumentów korporacyjnych.

Od roku 2012 portfel inwestycyjny GPFG jest zdywersyfikowany geograficznie według wartości PKB poszczególnych krajów (dla instrumentów dłużnych) oraz wartości rynkowej aktywów (dla instrumentów udziałowych) ${ }^{15}$. W ostatnim okresie większość aktywów funduszu plasowana była na rynkach europejskich. Sytuacja ta ma się zmienić w kolejnych latach (tabela 3), aby zapewnić funduszowi odpowiednią dywersyfikację ryzyka i optymalny poziom stóp zwrotu.

\footnotetext{
11 Ibidem.

12 http://www.regjeringen.no/en/dep/fin/Selected-topics/the-government-pension-fund/governmentpension-fund-global-gpfg.html?id=697027, dostęp 20.10.2012.

13 The Government Pension Fund Global (GPFG), Norwegian Ministry of Finance, Oslo 2012, s. 1.

14 Wealth Funds. Generally Accepted Principles and Practices „Santiago Principles”, op.cit., s. 41.

15 The Government Pension Fund Global (GPFG), op.cit., s. 1.
} 
Tabela 3. Struktura geograficzna indeksu referencyjnego Państwowego Funduszu Emerytalnego Global

\begin{tabular}{|l|c|c|}
\hline $\begin{array}{c}\text { Udział inwestycij w aktywach ogótem } \\
\text { w \% }\end{array}$ & $\begin{array}{c}\text { Indeks referencyjny obowiązujący } \\
\text { w 2011 r. }\end{array}$ & $\begin{array}{c}\text { "Nowy" indeks referencyjny } \\
\text { obowiązujący od 2012 r. }\end{array}$ \\
\hline Ameryka/Afryka & 35 & 40 \\
\hline Europa & 54 & 41 \\
\hline Azja/Oceania & 11 & 19 \\
\hline w tym kraje rozwijające się & 6 & 10 \\
\hline
\end{tabular}

Źródło: The Management of the Government Pension Fund in 2011, Norwegian Ministry of Finance, Oslo 2012, s. 46.

Dotychczasowa struktura geograficzna inwestycji GPFG na rynkach akcji powodowała, że fundusz stał się największym inwestorem instytucjonalnym w Europie (ponad 2\% udziału w europejskim rynku akcji, rysunek 1). Nowy indeks referencyjny obowiązujący od 2012 r. ma zmniejszyć ekspozycję akcyjnej części portfela inwestycyjnego funduszu na rynki europejskie - udział tej części w benchmarku został zredukowany aż o 13 punktów proc. Z drugiej strony ma się istotnie zwiększyć udział inwestycji na rynkach Azji i Oceanii (o 8 punktów proc.) oraz obu Ameryk i Afryki (o 5 punktów proc.).

\section{Rysunek 1. Udział Państwowego Funduszu Emerytalnego Global w regionalnych} rynkach akcji w latach 1999-2012 (w \%)

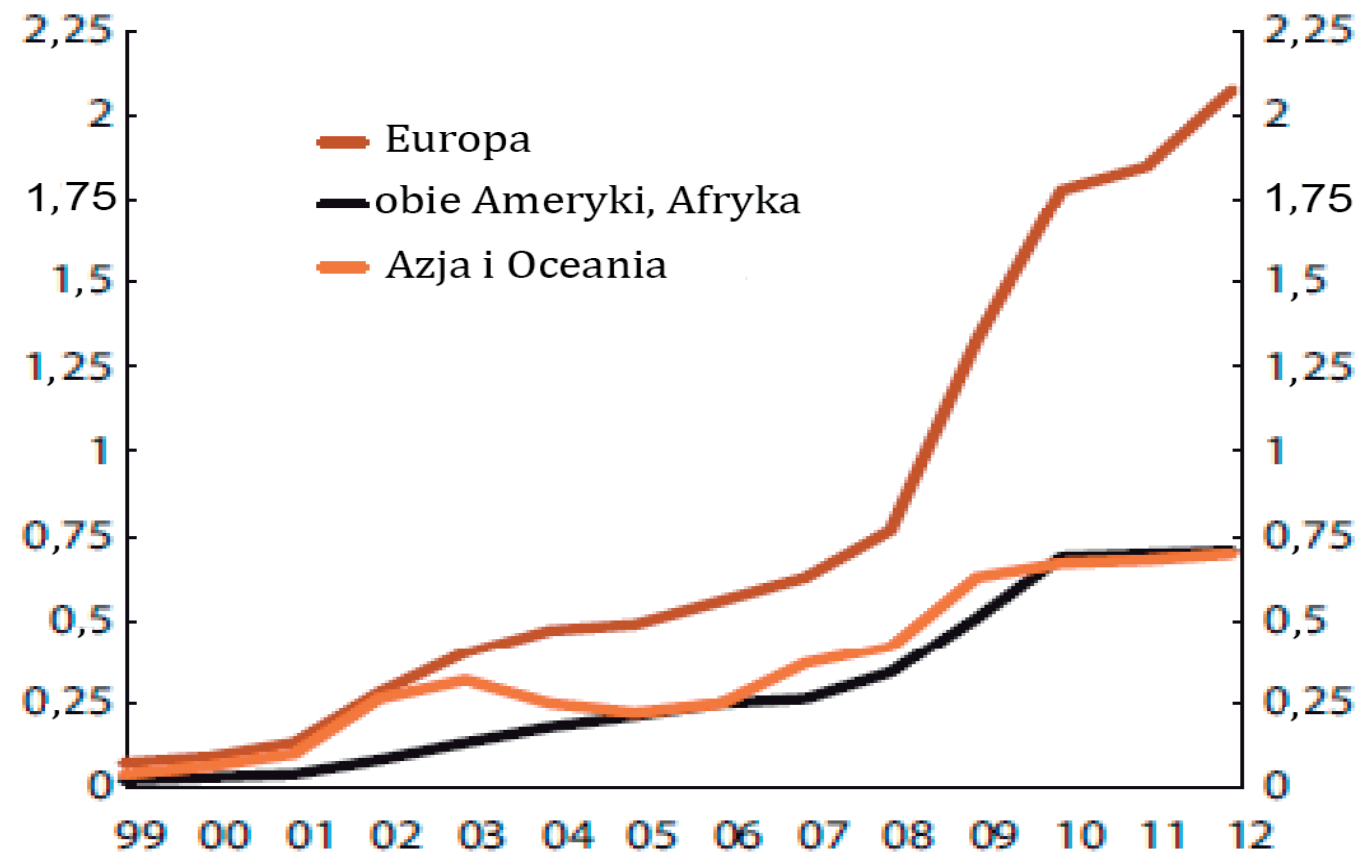

Źródło: The Management of the Government Pension Fund in 2011, Norwegian Ministry of Finance, Oslo 2012, s. 132. 


\section{Rysunek 2. Udział Państwowego Funduszu Emerytalnego Global w regionalnych} rynkach instrumentów dłużnych w latach 1998-2012 (w \%)

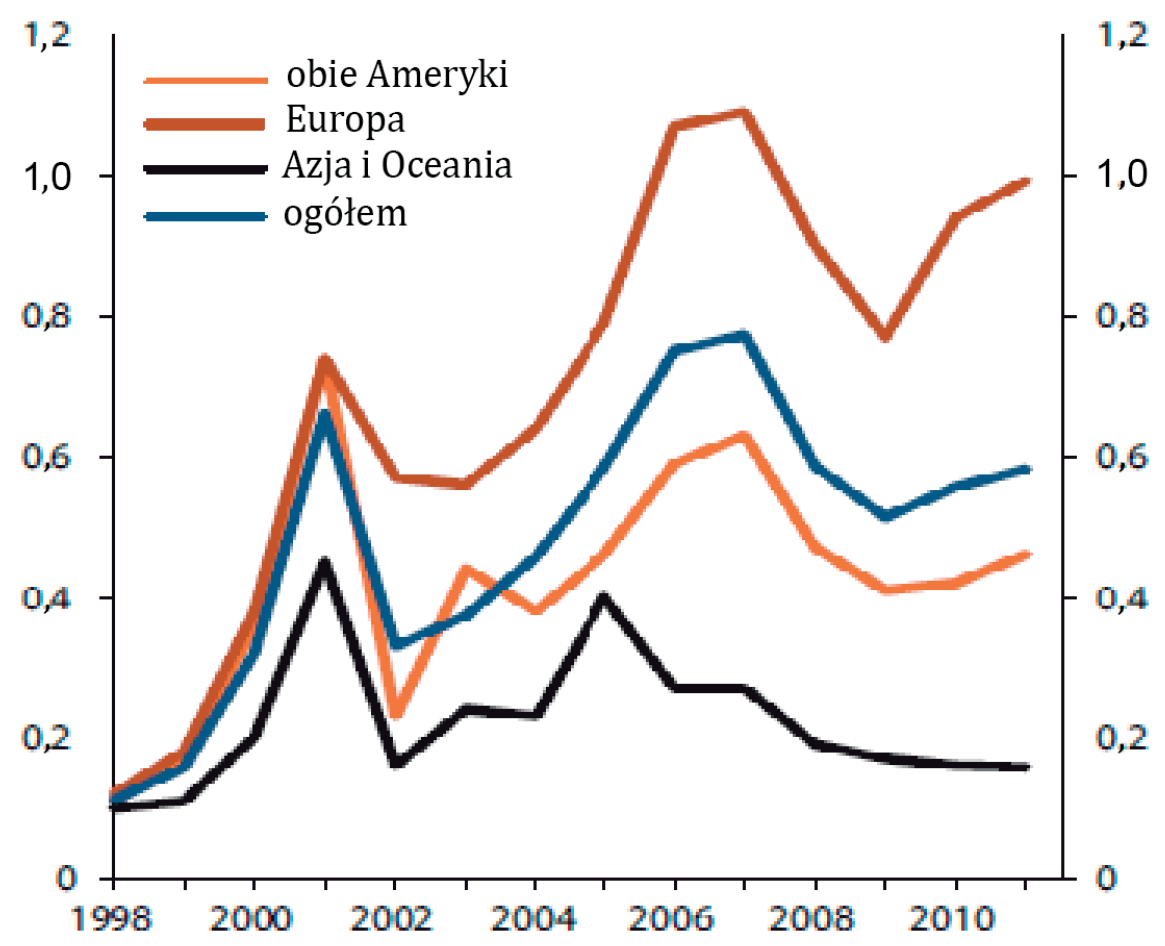

Źródło: The Management of the Government Pension Fund in 2011, op.cit., s. 68.

Warto zwrócić uwagę, że w 2004 r. przyjęto regulacje dotyczące etycznego inwestowania środków zgromadzonych w funduszu, które bazują na dwóch zasadach: 1) zapewnieniu, że znaczna część narodowego bogactwa pochodzącego z ropy naftowej zostanie przekazana kolejnym pokoleniom, 2) niepodejmowania nadmiernego ryzyka, zwłaszcza związanego z inwestycjami etycznie wątpliwymi. Wówczas postanowiono także wykluczyć nieetyczne przedsiębiorstwa (ich listę ogłasza Ministerstwo Finansów po zasięgnięciu opinii Rady Etyki ${ }^{16}$ ) z katalogu inwestycji, w które może być zaangażowany GPFG.

${ }^{16} \mathrm{Na}$ liście tej znajdują się m.in. firmy produkujące papierosy (np. British American Tobacco Plc., Philip Morris Int. Inc., Japan Tobacco Inc., Imperial Tobacco Group Plc.), broń nuklearną (m.in. Lockheed Martin Corp., Boeing Co.), łamiące prawa człowieka (np. Wal-Mart Stores Inc.) czy też powodujące zniszczenia środowiska. Wykluczenia dotyczą także państw emitentów papierów dłużnych. Dotychczas Ministerstwo Finansów zakazało inwestycji w obligacje Korei Północnej, Syrii i Iranu, jeśli tylko państwa te zdecydują się w przyszłości na emitowanie tego typu papierów wartościowych. New decisions about the Government Pension Fund Global, http://www.regjeringen.no/en/dep/fin/news/news/2014/new-decisions-about-thegovernment-pensi.html?id=750091, dostęp 10.02.2014. 


\section{Efektywność inwestycyjna Państwowego Funduszu Emerytalnego Global}

Z biegiem lat fundusz okazał się dobrze spełniającym postawione przed nim cele w zakresie długoterminowego zarządzania oszczędnościami pochodzącymi z dochodów ze sprzedaży ropy naftowej, co pozwoli czerpać korzyści zarówno obecnym, jak i przyszłym pokoleniom obywateli. GPFG jest systematycznie zasilany przez jedną trzecią zysków, jakie Norwegia czerpie z wydobycia ropy naftowej, oraz powiększają go zyski z działalności inwestycyjnej, co powoduje, że są w nim zgromadzone znaczne aktywa - na koniec drugiego kwartału 2013 r. wartość funduszu wynosiła 4,4 bln NOK (około 2,2 bln PLN). Fundusz ten jest drugim największym na świecie (po Japonii) i pierwszym w Europie funduszem emerytalnym ${ }^{17}$.

Rysunek 3. Wartość aktywów Państwowego Funduszu Emerytalnego Global (GPFG) oraz Państwowego Funduszu Emerytalnego Norwegia (GPFN) w latach 1996-2013 (w mld NOK)

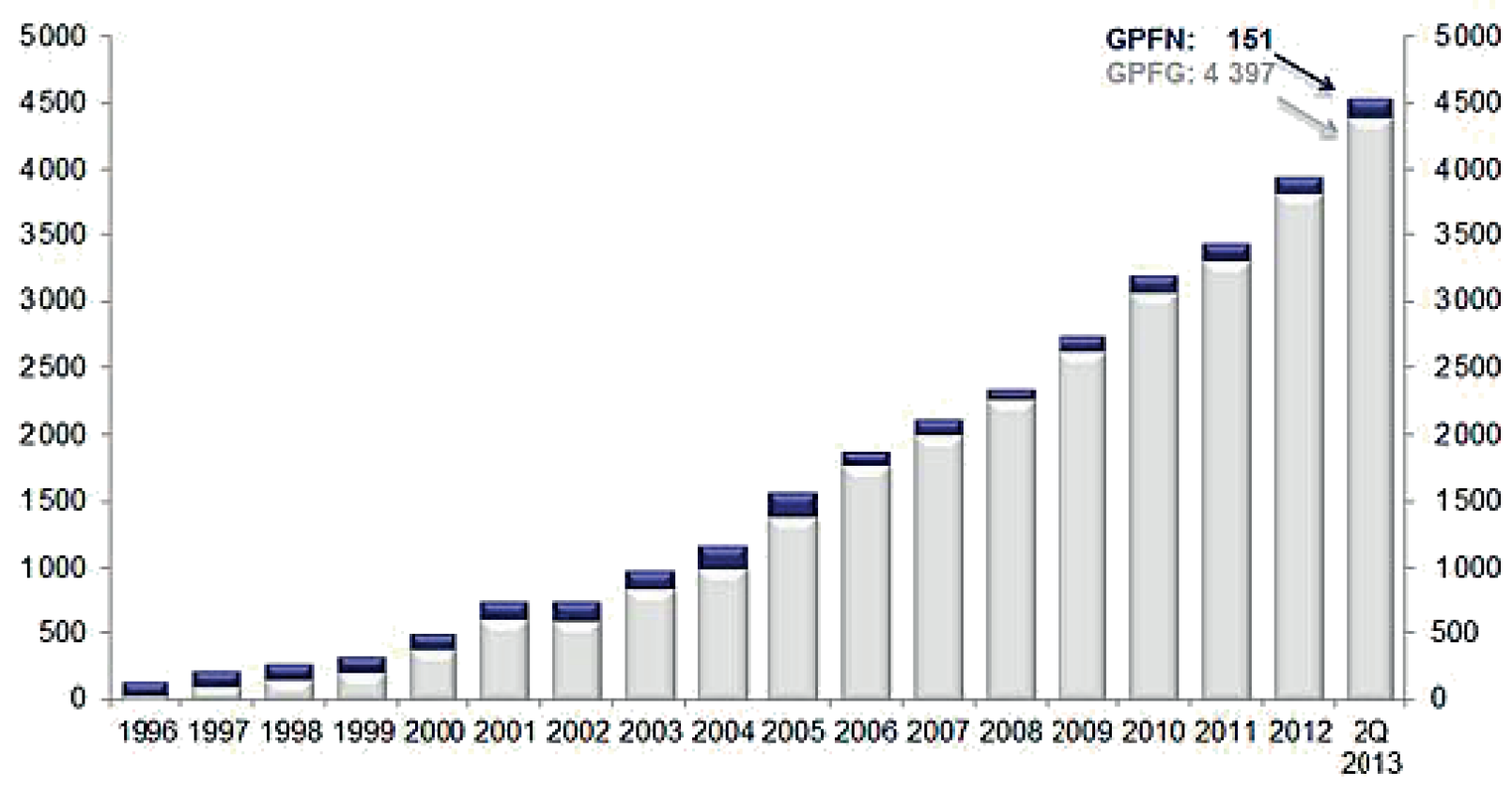

Źródło: Norges Bank i Ministerstwo Finansów Norwegii, http://www.regjeringen.no/en/dep/fin/Selectedtopics/the-government-pension-fund/market-value-of-the-government-pension-f.html?id=699635, dostęp 10.02. 2014.

Struktura portfela inwestycyjnego w latach 2006-2012 (tabela 4) odzwierciedlała w dużej mierze strukturę indeksu referencyjnego. W kolejnych latach fundusz

17 M. Mosionek-Schweda, op.cit., s. 117-118. 
notował dodatnie stopy zwrotu, z wyjątkiem sporego spadku wartości aktywów w roku 2008 (ponad 23\% na minusie) oraz niewielkiej straty w roku 2011. W 2012 r. po zmianie geograficznej struktury portfela inwestycyjnego fundusz osiągnął zysk równy $13,4 \%{ }^{18}$. W tym okresie zmniejszono ekspozycję na rynek europejski (z 53\% w 2011 r. do $48 \%$ aktywów w 2012 r.) i inwestowano w większym zakresie na rynkach wschodzących. Docelowo portfel ma być jeszcze bardziej zdywersyfikowany geograficznie, a udział inwestycji na rynku europejskim ma zostać zredukowany do około $40 \%$ wartości aktywów.

Tabela 4. Struktura i wartość portfela inwestycyjnego GPFG oraz stopy zwrotu w latach 2006-2012

\begin{tabular}{|l|c|c|c|c|c|c|c|}
\hline \multicolumn{1}{|c|}{ Wyszczególnienie } & 2006 & 2007 & 2008 & 2009 & 2010 & 2011 & 2012 \\
\hline Wartość portfela w mld NOK & 1784 & 2019 & 2275 & 2640 & 3077 & 3312 & 3816 \\
\hline Instrumenty dłużne w \% & 59,3 & 52,6 & 50,4 & 37,7 & 38,5 & 40,9 & 38,1 \\
\hline Instrumenty udziałowe w \% & 40,7 & 47,4 & 49,6 & 62,3 & 61,5 & 58,8 & 61,2 \\
\hline Inwestycje w nieruchomości w \% & 0 & 0 & 0 & 0 & 0 & 0,3 & 0,7 \\
\hline Stopa zwrotu w \% & 7,92 & 4,26 & $-23,31$ & 25,62 & 9,62 & $-2,52$ & 13,42 \\
\hline
\end{tabular}

Źródło: Opracowanie własne na podstawie: M. Mosionek-Schweda, op.cit., s. 122; The Management of the Government Pension Fund in 2011, op.cit., s. 142; The Management of the Government Pension Fund in 2012, op.cit., s. 43 i 101.

Biorąc pod uwagę cały okres funkcjonowania funduszu Global, zastosowana polityka inwestycyjna przyniosła dobre rezultaty. Średnia nominalna stopa zwrotu za okres 1998-2012 wyniosła 5,05\%, podczas gdy indeks referencyjny za ten sam okres był równy $4,78 \%$, przy rocznej inflacji na poziomie $1,92 \%$. Średnie roczne stopy zwrotu za okres 3, 5 i 10 lat wyniosły odpowiednio 6,61\%, 3,14\% i 5,99\%, przekraczając w każdym przypadku zysk obliczony na podstawie indeksu referencyjnego (przy średniej rocznej inflacji wynoszącej odpowiednio 2,25\%, 2,0\% i 2,15\% ${ }^{19}$. Wydaje się, że fundusz ma szanse osiągać doskonałe wyniki inwestycyjne również w kolejnych latach - głównie dzięki większej dywersyfikacji i inwestowaniu środków na nowych, wschodzących rynkach.

${ }_{18}$ R. Fixsen, Norwegian oil fund reports second highest return in 15-year history, „Investment and Pensions Europe" March 8, 2013, www.ipe.com

19 The Management of the Government Pension Fund in 2012, Meld. St. 27 (2012-2013) Report to the Storting (White paper), Norwegian Ministry of Finance, Oslo, June 2013, s. 47. 


\section{Zakończenie}

Norweskie emerytalne fundusze rezerwowe stały się w ciągu dwudziestu lat ich funkcjonowania jednym $z$ największych inwestorów instytucjonalnych na światowym rynku finansowym. Aktywa w nich zgromadzone przyciągają, ze względu na ich wartość, uwagę wszystkich uczestników rynków finansowych, a polityka inwestycyjna podlega szczegółowej i wnikliwej obserwacji. Samo utworzenie funduszy było i nadal jest przykładem odpowiedzialnej polityki państwa w zakresie zabezpieczenia społecznego swoich obywateli w długim okresie. Dzięki odłożonym środkom przyszłe pokolenia Norwegów będą miały zapewnioną wypłatę świadczeń emerytalnych, a wszystko w imię solidarności i sprawiedliwości społecznej w horyzoncie obejmującym kolejne dziesięciolecia.

Zgromadzenie tak dużych aktywów nie byłoby oczywiście możliwe bez wpływów ze sprzedaży ropy naftowej. Co prawda jeden z funduszy (Państwowy Fundusz Emerytalny Norwegia) tworzony był z nadwyżki występującej przejściowo w systemie ubezpieczeń społecznych, ma on jednak bardzo mały udział w całości zgromadzonych rezerw. Ponadto od kilku lat nie wpływają już do niego żadne nowe składki, a wzrost aktywów osiągany jest wyłącznie dzięki inwestycjom. Kluczową rolę odgrywa natomiast Państwowy Fundusz Emerytalny Global, którego wartość na koniec 2012 r. osiągnęła ponad 2 bln PLN. Oba fundusze zarządzane są przez odrębne niezależne podmioty, które muszą się jednak stosować do określonych w prawie zasad polityki inwestycyjnej. Fundusz Norwegia inwestuje przede wszystkim na rynku krajowym oraz rynkach państw sąsiadujących (nordyckich), natomiast inwestycje funduszu Global prowadzone są wyłącznie na rynkach zagranicznych. Żaden z funduszy nie musi osiągać minimalnej stopy zwrotu, jednak określone są indeksy referencyjne, z którymi porównywane są wyniki inwestycyjne funduszu w kolejnych okresach. Dzięki przyjęciu długoterminowej polityki inwestycyjnej i zapewnieniu stałego dopływu środków ze sprzedaży ropy naftowej GPFG może inwestować w mniej płynne aktywa i osiągać tym samym wyższe stopy zwrotu.

Dotychczasowa działalność lokacyjna funduszy potwierdziła, iż konsekwentnie prowadzona polityka inwestycyjna oraz prawidłowo określone jej ramy przynosić mogą stopy zwrotu wyższe od indeksów referencyjnych, nawet jeśli w krótkim okresie fundusz notować będzie spadki wartości portfela. Postępująca dywersyfikacja geograficzna aktywów funduszu Global powoduje, że norweskie rezerwy służą finansowaniu inwestycji już niemal w każdym miejscu na świecie. $Z$ portfela wyłączane są jednak inwestycje w przedsięwzięcia niespełniające podstawowych wymogów etycznych - firmy produkujące broń, koncerny tytoniowe, korporacje naruszające 
podstawowe prawa człowieka czy powodujące szkody środowiskowe. Państwowy Fundusz Emerytalny Global wyznacza tym samym standardy przejrzystego i etycznego inwestowania, będąc nierzadko wzorem do naśladowania dla innych inwestorów instytucjonalnych.

Przykład Norwegii pokazuje dobitnie, iż gromadzenie dużych rezerw emerytalnych możliwe jest jedynie w sytuacji długotrwałej nadwyżki budżetowej lub stałego zasilania funduszu $\mathrm{z}$ wpływów ze sprzedaży surowców. W innym przypadku występuje bowiem silna pokusa ze strony rządzących, aby wykorzystać rezerwy emerytalne do innych celów. W okresie rosnących deficytów w finansach publicznych odroczone potrzeby emerytalne przegrywają często $\mathrm{z}$ krótkoterminowymi potrzebami budżetowymi, zwłaszcza w obliczu zagrożenia przekroczenia kolejnego progu zadłużenia ${ }^{20}$. Rezerwy emerytalne topnieją wówczas wbrew przyjętym wcześniej harmonogramom przyszłych wypłat $\mathrm{z}$ funduszu, a aktywa zgromadzone w funduszach nie są w stanie pokryć wypłaty świadczeń $w$ dłuższym okresie ${ }^{21}$. Rosnące deficyty budżetowe w krajach posiadających rezerwy emerytalne powodują, iż idea tworzenia funduszy rezerwowych jest ostatnio mocno krytykowana.

Pomimo ewidentnych sukcesów w pomnażaniu środków mających sfinansować wypłatę świadczeń emerytalnych w przyszłości, krytyka nie omija również norweskich funduszy emerytalnych, w szczególności funduszu Global. W Norwegii trwa obecnie dyskusja, czy fundusz ten nie powinien zostać podzielony na co najmniej dwa mniejsze fundusze oraz czy nie należy zmienić jego strategii inwestycyjnej ${ }^{22}$. Pomysłodawcy zmian podnoszą argument zwiększenia konkurencji między funduszami, nieśmiało wspominając także o możliwościach inwestycji na rynku lokalnym. Warto jednak pamiętać, że podzielenie funduszu może okazać się rozwiązaniem tylko na chwilę - po pewnym czasie oba fundusze i tak osiągną bardzo duże rozmiary. Zmiany spowodują też niekorzystne skutki w obszarze kosztów funkcjonowania funduszu - wyjątkowo dotychczas niskie ${ }^{23}$ opłaty za zarządzanie uległyby zapewne istotnemu podwyższeniu.

20 Przykładem takiego postępowania jest Polska, która już kilka razy dokonywała wypłat z Funduszu Rezerwy Demograficznej (FRD), aby zaspokoić bieżące potrzeby związane z finansowaniem systemu ubezpieczeń społecznych (chodziło o zmniejszenie dotacji budżetu państwa do Funduszu Ubezpieczeń Społecznych). Zob. więcej: J. Rutecka, Fundusz Rezerwy Demograficznej - analiza działalności oraz konsekwencje przedterminowego wykorzystania aktywów, „Kwartalnik Kolegium Ekonomiczno-Społecznego Studia i Prace" 2013, nr 3 (15).

21 Przykładowo, środki zgromadzone w polskim Funduszu Rezerwy Demograficznej na koniec 2011 r. wystarczyłyby jedynie na wypłatę świadczeń emerytalnych przez nieco ponad 6 tygodni. Ibidem.

22 J. Williams, Norwegian oil fund: unification or division, „Investment and Pensions Europe” October 2013.

${ }^{23}$ Koszty zarządzania funduszem w 2012 r. wyniosły 0,06\% wartości aktywów. Ibidem. 


\section{Public pension reserve funds - the case of Norway}

Pensions reserve funds are permanent elements of social security systems in many countries. In others they play important role of a useful solution that helps to alleviate temporary deficits in social security. One of the few countries that gathered very large pensions reserves is Norway. It is an excellent example of a country that uses oil revenues to fulfil the long-term liabilities of the social security system and promote solidarity between generations. The article analyses the sources of fundraising and methods of asset management used in Norwegian public reserve funds. The collection of large reserves was possible only due to permanent surplus in state budget resulting from oil revenues. Assets collected in the fund were then invested in highly diversified and long-term portfolio that proved to be very effective. Norwegian pension reserve fund Global showed that the right strategies of asset allocation and broad geographical diversifications may result in rates of return much higher than constructed benchmarks. Moreover, it can also meet the expectations of ethical and socially-responsible investments.

Keywords: old-age pension system, reserve funds, pension reserves, pension assets, sovereign wealth funds

\section{Le fonctionnement des fonds de pension publics - le cas de la Norvège}

Les fonds de réserve pour les retraites sont des éléments permanents des systèmes de sécurité sociale dans de nombreux pays. Dans d’autres pays, ils jouent un rôle important d'une solution utile qui contribue à atténuer les déficits temporaires dans la sécurité sociale. La Norvège est l'un des rares pays qui ont déjà accumulé de vastes montants de réserves. C'est un excellent exemple d'un pays qui utilise les revenus du pétrole pour remplir les engagements à long terme du système de sécurité sociale et pour promouvoir la solidarité entre les générations. L'article analyse les sources de financement et les méthodes de gestion d'actifs utilisés dans les fonds de réserve publics norvégiens. La collection de grandes réserves a été possible grâce à l'excédent permanent dans le budget de l'Etat résultant des revenus pétroliers. Les actifs collectés dans les fonds ont été investis dans un portefeuille largement diversifié et à long terme. L'auteur caractérise le fonctionnement du Fonds de pension public «Norvège» et du Fonds de pension public «Global». Il décrit en détail la politique d'investissement poursuivie et il évalue les performances des investissements réalisés par les fonds de réserve. A la fin, il présente des propositions 
visant à modifier les règles de fonctionnement pour ces fonds, en les analysant à travers le prisme des mesures prises par les gouvernements d'autres pays en face de la hausse des déficits budgétaires.

Mots-clés: le système de retraite, les fonds de réserve, les fonds de pension, les réserves pour les retraites, les actifs de retraite, les fonds souverains

\section{Государственные пенсионные резервные фонды - казус Норвегии}

Пенсионные резервные фонды являются постоянным элементом систем социального обеспечения во многих странах. Они играют важную роль, помогая облегчить их временные дефициты. Одной из немногих стран, у которой значительные по размерам пенсионные резервные фонды, является Норвегия. Это отличный пример страны, которая использует нефтяные доходы для выполнения долгосрочных социальных обязательств и укрепления солидарности между поколениями. В статье подвергаются анализу источники привлечения средств и методы управления активами, используемые в норвежских государственных резервных фондах. Накопление больших объемов резервов стало возможным только благодаря постоянному профициту государственного бюджета, получаемому в результате нефтяных доходов. Норвежский пенсионный фонд Global показал, что правильные стратегии распределения активов и широкая географическая диверсификация могут привести к ставкам доходности значительно превышающим построенные ориентиры. Кроме того, эти инвестиции могут соответствовать этическим ожиданиям и связанным с ними ожиданиям социальной ответственности.

Ключевые слова: система пенсионных фондов по старости, резервные фонды, пенсионные резервы, пенсионные активы, фонды национального благосостояния 